\title{
Effectiveness of Using Instagram as a Promotion Media in the Era of the Covid-19 Pandemics
}

\author{
Lina Asmara Wati ${ }^{1,2 *}$, Muhammad Permana Hendra Safii ${ }^{1}$, Riski Agung Lestariadi ${ }^{1}$, \\ Supriyadi Supriyadi ${ }^{3}$ \\ ${ }^{1}$ Social and Economic Fisheries Departement, University Brawijaya, Malang, Indonesia \\ ${ }^{2}$ Research Group: The Resilience of Coastal and Fisheries Village (Recofish), Universitas Brawijaya \\ ${ }^{3}$ Social and Economic Fisheries Departement, University Brawijaya, Kediri, Indonesia \\ *Corresponding author. Email: linaasmara@ub.ac.id
}

\begin{abstract}
The development of digital technology is an opportunity for business owners to market their products using social media or digital marketing. Digital marketing is a promotional activity and reaches a broader market to develop businesses. The FOS Food Mojokerto restaurant also employs the use of social media to carry out online promotions. This study aimed to measure Instagram's effectiveness as a promotional medium at FOS Food Mojokerto Restaurant in the Covid 19 pandemic era and analyze the effect of promotion on sales volume of FOS Food Mojokerto Restaurant in the Covid 19 pandemic era. FOS Food is a business engaged in seafood culinary which was founded in 2015 and became the pioneer of the first seafood processing company in Mojokerto by carrying out the concept of eating seafood at the table. Incidental sampling technique to 108 respondents was used in this study. The results showed that using Instagram social media as a promotional medium by FOS Food Restaurant using the EPIC model was categorized as effective, which was on an effective scale of 3.41-4.21. The EPIC rate result was 3.975 from the average value of the dimensions of empathy, persuasion, impact, and communication. The effect of promotion on sales volume does consider less effective because the respondents' answers show a value of $36.1 \%$ disagree, $30.6 \%$ quite agree, and 2.99 on average.
\end{abstract}

Keywords: Covid-19, Effectiveness, Instagram, Promotion

\section{INTRODUCTION}

Technology in this digital era is progressing rapidly. The rapid development of technology certainly has an impact on the marketing business world. In 2020, various countries around the globe experienced negative effect due to the spread of the Coronavirus (Covid 19), different anticipatory actions by suggesting social distancing. According to Wati [1] this time, in the digital era, a business cannot be separated from digital marketing; this is by the explanation of technological developments. The existence of Small and Medium Enterprises (SMEs) in Indonesia is a driving factor in the creation of national economic development because it can spur economic growth. According to Elena [2] Now, for an organization, social media is a must-necessity as a tool to manage relationships with customers and facilities that can increase customer loyalty. Hariyanti [3] stated that, a 
philosophy and business strategy that is supported by technology platforms, business rules, workflows, processes and social characters.

As a result of the weakening of the economy due to the declining purchasing power of consumers Furthermore, most markets have been forced to close to avoid the spread of Covid 19. Many traders have lost their stalls because of the implementation of the PSBB (also known as Pembatasan Sosial Berskala Besar or Large-Scale Social Restrictions); inevitably, business actors must find shortcuts to avoid more significant losses due to policies to inhibit the spread of COVID19. Seeing the large number of Indonesians who use social media creates opportunities for businesspeople in the era of the Covid 19 pandemics to use social media as media marketing to promote sales.

The first advantage of internet media marketing for business actors, include unlimited working hours (i.e. 24 hours/day). This means business activities can be carried out anytime and without time limits, as long as there are devices with internet available. Online promotion may be carried out automatically and simultaneously, thus it can save time and energy. The most important aspect of using the internet is that it is more economical with extensive area coverage. More business actors may find it easier to introduce products to the public [4].

Therefore, internet can be used as a strategy that can support marketing goals due to its function as a marketing medium. Many businessmen take advantage of existing internet-based media, for example, social media. Many Indonesian people use social media to interact socially and communicate online. Still, it can also use as a business activity, and one of the social media widely used is Instagram. Many social media users create an opportunity that some business actors use to take advantage of social media as a promotional medium. The FOS Food Mojokerto restaurant is one of the restaurant businesses that use Instagram social media as a promotional medium. Charoensukmongkol and Sasatanun stated that [5], using social media as a marketing tool also helps companies to reduce operating costs that are usually generated in traditional marketing without social media. And according to Ibrahim [6], as we often see in modern times, the most effective promotional media is promotion through social media and one of the social media that is very loved by the public today is Instagram.

The rapid development of technology has led to an increase in the use of social media. It makes social media a very potent medium to use as a promotional medium by business actors. In the current pandemic conditions, the restaurant business has experienced a decline. The social media that will often use by restaurant businesses in Mojokerto is Instagram. FOS Food restaurant is a business engaged in culinary seafood founded in 2015 and became the pioneer of the culinary company in processing the first seafood in Mojokerto by carrying the concept of eating seafood at the table.

The purpose of this study was to analyze the effectiveness of Instagram social media as a promotional medium at FOS Food Mojokerto Restaurant during the Covid 19 pandemic based on the epic model and analyze the effect of promoting the use of Instagram social media on the sales volume of FOS Food Mojokerto Restaurant in the era of the Covid 19 pandemic. 


\section{RESEARCH METHODS}

\subsection{Type of Research}

This research was a type of descriptive research using a quantitative approach. According to Rukajat et al. [7], descriptive research is a study of a group of people, objects to describe the facts and the meaning of a problem to be solved.

\subsection{Types and Sources of Data}

There are two types of data in this study, namely primary data and secondary data.

\subsubsection{Primary Data}

Primary data must seek through data sources or respondents. The understanding of the object or respondent is the person we use to get information or data [8]. The primary data obtained in this study were the results of respondents' answers from questionnaires distributed to visitors to the FOS Food Mojokerto restaurant.

\subsubsection{Secondary Data}

Secondary data does obtain from a second source or not collected by the researcher [9]. In this study, secondary data was obtained from various sources of articles, reports, books, the internet, and journal

\subsection{Data Collection Techniques}

In the data collection technique, the method used in this study consisted of distributing questionnaires, interviews, and observations. The purpose of this data collection was to obtain accurate data and results according to the facts in the field.

1. The closed questionnaire was used in this study. That means this questionnaire did not allow respondents to expand answer, but to select the provided answers in this questioner.
2. Interviews were conduct in structured interviews with the owners and employees of FOS Food Mojokerto restaurant and discussions using unstructured techniques. In this case, the respondents answered the questions directly during the interview sessions.

3. Observation is observing the research object. Observations was done in two ways, include direct and indirect observation. The observation technique carried out in the research at the FOS Food Mojokerto restaurant include:

a) General condition

b) Documents related to marketing

c) Promotion process carried out on Instagram social media.

\subsection{Population and Sample}

The research was conducted at the FOS Food restaurant Jl. Semeru No.19, Magersari District, Mojokerto City, East Java. The population of this study is consumers or visitors who buy products from FOS Food Mojokerto restaurants. Characteristics of the sample used in this study are inclusion and inclusion in the sample criteria or characteristics needed by each member of the population does take as a sample in the survey [10]. The sampling method that will use is the incidental sampling technique. Random sampling is sampling by taking respondents who happen to be where they meet the researcher and are by the place of research. The sample size is calculated based on the linear time function using the following formula:

$$
\mathrm{N}=(\mathrm{T}-\mathrm{t} 0) / \mathrm{t}
$$

Where:

$\mathrm{n}=$ Minimum number of samples

$\mathrm{T}=$ Time available for research $(7$ days $=1,260$ minutes) 
$\mathrm{t} 0=$ Sampling time per day $(3$ hours $=180$ minutes $)$

$\mathrm{t}=$ Time taken by respondents to fill out the questionnaire (30 minutes/person)

The number of samples interviewed is 108 respondents. Questionnaires was distributed through online media or in person.

\subsection{Measurement Scale}

The measurement scale used in this study is the Linkert scale. According to Sugiyono [11], the Likert scale measures attitudes, opinions, and perceptions of a person or group of people about social phenomena in research. There are five alternative answers on the Likert scale measurement using five scales: strongly agree, agree, neutral, disagree, and strongly disagree. While the scoring method is that strongly agree 5, agree 4, neutral 3, disagree 2, and strongly disagree 1 .

a) For answers strongly agree (SS) is given a score of 5.

b) For the answer agree (S) given a score of 4.

c) For answers quite agree (CS) given a score of 3 .

d) For answers that do not agree (TS) given a score of 2.

e) For answers strongly disagree (STS) given a score of 1 .

\subsection{Validity and Reliability Test}

A validity test is a measuring tool used to measure the validity of a questionnaire. Imam [12] states that the validity test did use to measure the validity of a questionnaire.

To test the validity of the questionnaire in this study using the correlation coefficient formula as follows:

$r=\frac{n \sum x y-\left(\sum x\right)\left(\sum y\right)}{\sqrt{\left\{n \sum x^{2}-\left(\sum x\right)^{2}\right\}\left\{n \sum y^{2}-\left(\sum y\right)^{2}\right\}}}$

The test at the significant level used is $5 \%$; if $r$ count $>r$ table, then the questionnaire is valid, while if $r$ arithmetic $<r$ table, then the questionnaire is said to be invalid.

A reliability test is a tool in research to test and find out whether a questionnaire used for data collection of a study can be said to be tested or not said to will be testing if the test on the questionnaire is repeated measurements.

In this study, the reliability test used the Cronbach Alpha formula, following this formula:

$r_{11}=\left(\frac{k}{k-1}\right)\left(1 \frac{\sum \sigma_{b}^{2}}{V_{1}^{2}}\right)$

The alpha coefficient assessment is as follows: If the value of Cronbach's Alpha (0.6) means that it is reliable if the value of Cronbach's Alpha $<(0.6)$ means that it is not reliable.

\subsection{Data Analysis Technique}

To analyze the effectiveness of Instagram social media can be measured using the epic model developed [6]. The Epic Model consists of four dimensions, including Empathy, Persuasion, Impact, and Communication.

Furthermore, from the four dimensions of the epic model and the results of filling out the questionnaire, the first step is to use a simple tabulation analysis as 
follows:

a. Simple Tabulation Analysis.

The data obtained from the results of filling out the questionnaire by the respondents were processed into percentage form using the following formula:

$$
\mathrm{P}=\frac{F_{i x} \quad 100 \%}{\sum \mathrm{Fi}}
$$

Where:

$\mathrm{P}=$ Total percentage of respondents who have a certain category

$\mathrm{Fi}=$ Number of respondents who have a certain category

fi $=$ Number of respondents

\section{b. Average Score}

The questionnaire that the respondent on each question has answered will be giving weight. Furthermore, the average score will calculate with the following formula:

$X=\frac{\sum \mathrm{fi} \cdot w i}{\sum \mathrm{fi}}$

\section{Where:}

$\mathrm{X}=$ weighted average

$\mathrm{Fi}=$ total number of frequencies

wi $=$ weight

$\mathrm{fi}=$ number of respondents who choose a certain category

The next step is to determine the rating scale to function as a determinant of respondents' responses by using the score value of each variable. The alternative weight of the ranking scale technique uses a scale between 1 to 5 , which determines the very negative position to the very positive position, then the calculation of the scale range uses the following formula:

$$
\mathrm{Rs}=(\mathrm{R}) / \mathrm{M}
$$

Where :

$$
\begin{array}{ll}
\text { Rs } & =\text { scale range } \\
\mathrm{R}(\text { weight }) & =\text { smallest largest weight } \\
\mathrm{M} & =\text { Number of scale categories }
\end{array}
$$

The scale used in this study is the Linkert scale with a score scale of 1 to 5 ; the rating scale that has been obtaining is 0.8 with the following results:

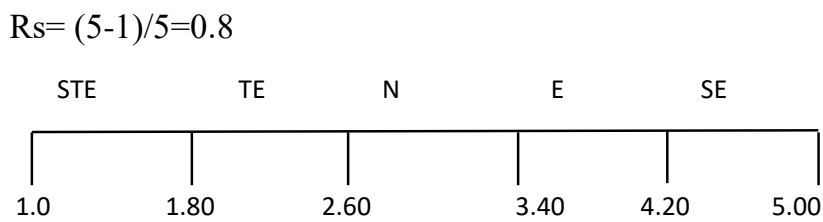

After the average score for each dimension of the EPIC Model is Empathy, Persuasion, Impact, and Communication will enter the average value in a range of scales to determine the effectiveness of each dimension of the epic model. The last step of the epic model analysis is to determine the epic rate value using the following formula:

$\underline{(x \text { empathy }+x \text { persuasion }+x \text { Impact }+x \text { Communication }}$

Epic Rate $=$

$\frac{(x \text { empathy }+x \text { persuasion }+x \text { Impact }+x \text { Communication }}{4}$

pic Rate $=$

$\underline{(x \text { empathy }+x \text { persuasion }+x \text { Impact }+x \text { Communication }}$

The result of the Epic Rate is an illustration of the promotion of a product. According to the respondent's perception, the scale range is as determined in the table above. 


\section{RESULTS AND DISCUSSION}

FOS Food restaurant is a subsidiary of CV FOS Jaya, which located in the city of Mojokerto precisely on Jalan Semeru no 19 Mojokerto City. It firstly established in 2016 starting from ordering online until the initiative to open a small shop by renting a former home garage to developing the shop becomes a restaurant. The restaurant business FOS Food obtains raw materials from its lobster cultivation and coastal fishers. In marketing its products and getting a broad market, this business chooses Instagram social media with the account name @FOS_food_factory to promote its products which now has 38 followers, 4 thousand on Instagram and every day posting product promotions almost two times in 1 day posting in the form of videos or photos as well as information containing restaurant opening hours, menus offered and prices.

\subsection{Characteristics of respondents}

The number of respondents was 108 on average, dominated by male consumers with a total of 55 respondents, and aged between 26-35 years with 44 respondents, dominated by respondents who resided in the city of Mojokerto with 45 respondents. The location of the restaurant in the city of Mojokerto. For the last education, it does dominate by respondents who have the last education of Senior High School as many as 75 people, the characteristics of the respondents are mostly types of work as private workers as many as 38 respondents. With expenses (Per month) mostly less than IDR 2,500,000 with a total of 57 respondents.

\subsection{Research Instrument Test}

The data instrument test does carry out on a distributed questionnaire. Test the validity and reliability of the questionnaire, which includes the epic model question items consisting of four dimensions of Empathy, Persuasion, Impact, Communication, and question items about sales volume.

\subsubsection{Validity test}

a) Validity test on the questions of the empathy dimension

Table 1 shows the results from the validity test of the questions on the empathy dimension.

Table 1. Validity test results on the empathy dimension

\begin{tabular}{|c|c|c|c|c|}
\hline No & Question Item & R count & R table & Description \\
\hline 1 & E1 & 0.488 & 0.187 & Valid \\
\hline 2 & E2 & 0.249 & 0.187 & Valid \\
\hline 3 & E3 & 0.492 & 0.187 & Valid \\
\hline 4 & E4 & 0.607 & 0.187 & Valid \\
\hline 5 & E5 & 0.468 & 0.187 & Valid \\
\hline 6 & E6 & 0.692 & 0.187 & Valid \\
\hline
\end{tabular}

Source: Primary Data, 2021

The calculated $\mathrm{R}$ value for the question item (E1) is 0.488 which is considered valid because $\mathrm{R}$ count is greater than $\mathrm{R}$ table, the $\mathrm{R}$ count calculated value for the question item (E2) is 0.249 which is considered valid because $\mathrm{R}$ count is greater than $\mathrm{R}$ table, the $\mathrm{R}$ count calculated value for the question item (E3) is 0.492 which is considered valid because $R$ count is greater than $\mathrm{R}$ table, the $\mathrm{R}$ count calculated value for the question item (E4) is 0.607 which is considered valid because $\mathrm{R}$ count is greater than $\mathrm{R}$ table, the $\mathrm{R}$ count calculated value on the question item (E5) of 0.468 which is considered valid because $R$ count is greater than $\mathrm{R}$ table and the calculated $\mathrm{R}$ value on the question item (E6) of 0.692 while the R table value of 0.187 which is considered valid because $R$ count is greater than $\mathrm{R}$ table. 
b) Validity test on the question item dimension of persuasion

Table 2 shows the results from the validity test of the questions on the persuasion dimension.

Table 2. Validity test results on the persuasion dimension

\begin{tabular}{|c|c|c|c|c|}
\hline No & $\begin{array}{c}\text { Question } \\
\text { Item }\end{array}$ & R count & R table & Description \\
\hline 1 & P1 & 0.676 & 0.187 & valid \\
\hline 2 & P2 & 0.461 & 0.187 & valid \\
\hline 3 & P3 & 0.635 & 0.187 & valid \\
\hline
\end{tabular}

Source: Primary Data, 2021

The calculated $\mathrm{r}$ value for the question item (P1) is 0.676 which is considered valid because $r$ count is greater than $\mathrm{R}$ table, the $\mathrm{R}$ count calculated value for the question item, the calculated $\mathrm{R}$ value for the question item $(\mathrm{P} 2)$ is 0.461 which is considered valid because $R$ count is greater than $R$ table, and the calculated $R$ value for the question item (P3) is 0.635 while the $\mathrm{R}$ table value is 0.187 . In the validity test, the question item is said to be valid if $\mathrm{R}$ count is greater than $\mathrm{R}$ table.

c) Validity test on the question item of the impact dimension

Table 3 shows the results from the validity test of the questions on the impact dimension.

Table 3. Validity Test Results on the Impact Dimension

\begin{tabular}{|c|c|c|c|c|}
\hline No & $\begin{array}{c}\text { Question } \\
\text { Item }\end{array}$ & R count & R table & Description \\
\hline 1 & I1 & 0.733 & 0.187 & valid \\
\hline 2 & I & 0.575 & 0.187 & valid \\
\hline 3 & I3 & 0.569 & 0.187 & valid \\
\hline
\end{tabular}

Source: Primary Data, 2021
Question items on the impact dimension are denoted I1 to I3. The calculated $\mathrm{R}$ value of the question item (I1) is 0.733 which is considered valid because $\mathrm{R}$ count is greater than $\mathrm{R}$ table, the calculated $\mathrm{R}$-value of the question item (I2) is 0.575 which is considered valid because $\mathrm{R}$ count is greater than $\mathrm{R}$ table, and the calculated R-value of the question item (I3) is 0.569 , while the $\mathrm{R}$ table value is 0.187 which is considered valid because $R$ count is greater than $R$ table. In the validity test, the question item is valid if the $R$ count is greater than the $\mathrm{R}$ table. From this statement, it can conclude that all impact dimension questions are said to be valid.

d) Validity test on the question item of the communication dimension

Table 4 shows the results from the validity test of the questions on the communication dimension.

Table 4. Validity test results on the communication dimension

\begin{tabular}{|c|c|c|c|c|}
\hline No & $\begin{array}{c}\text { Question } \\
\text { Item }\end{array}$ & $\begin{array}{c}\mathrm{R} \\
\text { count }\end{array}$ & $\mathrm{R}$ table & Description \\
\hline 1 & $\mathrm{C} 1$ & 0.588 & 0.187 & valid \\
\hline 2 & $\mathrm{C} 2$ & 0.597 & 0.187 & Valid \\
\hline 3 & $\mathrm{C} 3$ & 0.416 & 0.187 & Valid \\
\hline 4 & $\mathrm{C} 4$ & 0.641 & 0.187 & valid \\
\hline
\end{tabular}

Source: Primary Data, 2021

The calculated $\mathrm{R}$ value for the question item $(\mathrm{C} 1)$ is 0.588 which is considered valid because $\mathrm{R}$ count is greater than $\mathrm{R}$ table, the calculated $\mathrm{R}$ value for the question item (C2) is 0.597 which is considered valid because $\mathrm{R}$ count is greater than $\mathrm{R}$ table, the calculated $R$ value for the question item (C3) is 0.416 which is considered valid because $\mathrm{R}$ count is greater than $\mathrm{R}$ table and the calculated $\mathrm{R}$ value for the question item 
(C4) is 0.614 while the $\mathrm{R}$ table value is 0.187 in the validity test, the question item is said to be valid if $R$ count is greater than $\mathrm{R}$ table. From this statement, it can be concluded that all questions on the Communication dimension are said to be valid.

e) Validity test on the question item on the sales volume of the FOS Food restaurant during the Covid 19 pandemic

Table 5 shows the results from the validity test of the questions on the sales volume.

Table 5. Validity test results on sales volume

\begin{tabular}{|c|c|c|c|c|}
\hline No & $\begin{array}{c}\text { Question } \\
\text { Item }\end{array}$ & $\mathrm{R}$ count & $\begin{array}{c}\mathrm{R} \\
\text { table }\end{array}$ & Information \\
\hline 1 & $\mathrm{~V} 1$ & 0.757 & 0.187 & Valid \\
\hline 2 & $\mathrm{~V} 2$ & 0.829 & 0.187 & Valid \\
\hline 3 & $\mathrm{~V} 3$ & 0.697 & 0.187 & Valid \\
\hline
\end{tabular}

Source: Primary Data, 2021

The question item Sales Volume of the FOS Food restaurant is denoted $\mathrm{V} 1$ to $\mathrm{V} 3$. The value of the $\mathrm{R}$ count of question items (V1) is 0.757 which is considered valid because $\mathrm{R}$ count is greater than $\mathrm{R}$ table, the value of $\mathrm{R}$ count on question items (V2) is 0.829 which is considered valid because $\mathrm{R}$ count is greater than $\mathrm{R}$ table, and the $\mathrm{R}$ count of question items (V3) is 0.697 which is considered valid because $r$ count is greater than $r$ table. The question item is valid in the validity test if the $r$ count is greater than the $r$ table. From this statement, it can conclude that all sales volume questions are valid.

\subsubsection{Reliability Test}

Empathy, persuasion, impact, communication, and sales volume variables with a Cronbach Alpha value greater than the $60 \%$ significance stage $(0.6)$, it can conclude that the five variables can be said to be reliable, as shown in Table 6.

Table 6. Validity Test Results on Sales Volume

\begin{tabular}{|c|l|c|c|}
\hline No & \multicolumn{1}{|c|}{ Variable } & $\begin{array}{c}\text { Cronbach } \\
\text { Alpha }\end{array}$ & Description \\
\hline 1 & Empathy & 0.707 & reliable \\
\hline 2 & Persuasive & 0.675 & reliable \\
\hline 3 & Impact & 0.718 & reliable \\
\hline 4 & Communication & 0.688 & reliable \\
\hline 5 & Sales Volume & 0.783 & reliable \\
\hline
\end{tabular}

Source: Primary Data, 2021

\subsection{Promotion Effectiveness Analysis Based on the Epic Model}

\subsubsection{Dimension of Empathy}

The calculation of the average score of each item of empathy dimension questions is denoted $\mathrm{X}(\mathrm{E} 1)$ to $\mathrm{X}(\mathrm{E} 6)$. The calculation of the score is as follows:

$$
\begin{array}{r}
\mathrm{X}(\mathrm{E} 1)=\frac{(1 \times 0)+(2 X 0)+(3 X 11)+(4 \times 74)+(5 \times 23)}{108} \\
=4.111 \\
\mathrm{X}(\mathrm{E} 2)=\frac{(1 \times 0)+(2 X 0)+(3 \times 8)+(4 \times 45)+(5 \times 55)}{108} \\
=4.435 \\
X(\mathrm{E} 3)=\frac{(1 \times 0)+(2 X 1)+(3 \times 9)+(4 \times 63)+(5 \times 35)}{108} \\
=4.222 \\
X(\mathrm{E} 4)=\frac{(1 \times 0)+(2 X 1)+(3 \times 13)+(4 \times 52)+(5 \times 42)}{108} \\
=4.250
\end{array}
$$




$$
\begin{gathered}
X(\mathrm{E} 5)=\frac{(1 \times 0)+(2 X 2)+(3 \times 19)+(4 \times 53)+(5 \times 34)}{108} \\
=4.101 \\
X(\mathrm{E} 6)=\frac{(1 \times 0)+(2 X 1)+(3 \times 11)+(4 \times 54)+(5 \times 42)}{108} \\
=4.268
\end{gathered}
$$

The calculation to determine the average score of the empathy dimension (empathy).

$$
\begin{aligned}
& \text { X Empathy (E) } \\
& =\frac{4.111+4.435+4.222+4.250+4.101+4.268}{6} \\
& =4.231
\end{aligned}
$$

To determine the level of effectiveness of the Empathy dimension, that is, by entering the average value into the range of the effectiveness rating scale seen in Figure.

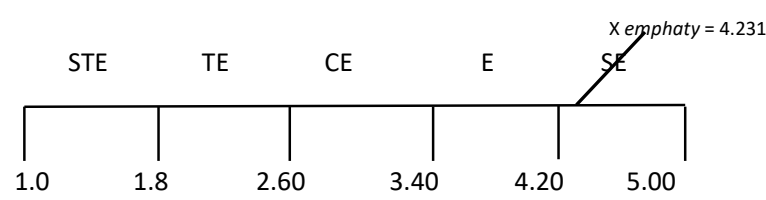

Based on the results of measuring the effectiveness of the empathy dimension, it can conclude that the promotions carried out by FOS Food restaurants on a scale range are very effective with an average value of 4.231 from the statement indicating that the promotions carried out by FOS Food make consumers feel like and happy after seeing the promotion. This case also shows that the promotion provides valuable information about the attractiveness of FOS Food restaurant products and gives consumers a feeling of pleasure and liking.

\subsubsection{Dimension of Persuasion}

The calculation of the average score of each item of persuasion questions is denoted $\mathrm{X}(\mathrm{P} 1)$ to $\mathrm{X}(\mathrm{P} 3)$. The calculation of the score is as follows:

$$
\begin{gathered}
X(\mathrm{P} 1)=\frac{(1 \times 0)+(2 X 0)+(3 X 13)+(4 \times 67)+(5 \times 28)}{108}=4.138 \\
X(\mathrm{P} 2)=\frac{(1 \times 0)+(2 X 1)+(3 \times 59)+(4 \times 40)+(5 \times 8)}{108}=3.509 \\
X(\mathrm{P} 3)=\frac{(1 \times 0)+(2 X 0)+(3 X 10)+(4 x 65)+(5 \times 33)}{108}=4.121
\end{gathered}
$$

Then the next step is to perform calculations to determine the average score of the dimension of persuasion. The calculation of the average score of each item of persuasion dimension questions (persuasion) is as follows:

$$
\mathrm{X} \text { Persuation }(\mathrm{P})=\frac{4.138+3.509+4.121}{3}=3.922
$$

To find out the level of effectiveness of the persuasion dimension, that is by entering the average value into the range of the effectiveness assessment scale as shown in the following figure:

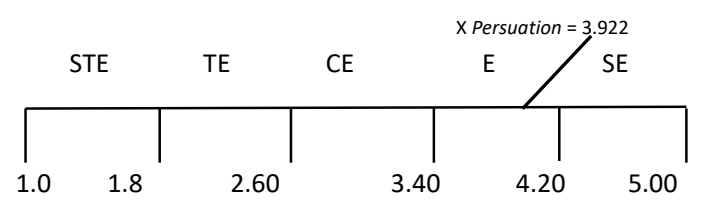

Based on the measurement of the effectiveness of the persuasion dimension, it can conclude that the promotions carried out by FOS Food restaurants are on an effective scale, with an average value of 3.992 . From the statement, it shows that the promotions carried out by Fos Food provide information that consumers can trust and strengthen consumers' purchasing decisions for the product

\subsubsection{Dimension of Impact}


The calculation of the average score of each item of impact questions is denoted $\mathrm{X}(\mathrm{I} 1)$ to $\mathrm{X}(\mathrm{I} 3)$. The calculation of the score is as follows:

$$
\begin{aligned}
& X(\mathrm{I} 1)=\frac{(1 \times 0)+(2 X 7)+(3 X 25)+(4 \times 61)+(5 \times 15)}{108}=3.777 \\
& X(I 2)=\frac{(1 \times 0)+(2 X 1)+(3 \times 46)+(4 \times 48)+(5 \times 13)}{108}=3.675 \\
& X(I 3)=\frac{(1 \times 0)+(2 X 0)+(3 X 30)+(4 x 57)+(5 \times 21)}{108}=3.916
\end{aligned}
$$

The calculation of the average score of each question item from the impact dimension is as follows:

$$
\mathrm{X} \text { impact }(\mathrm{I})=\frac{3.777+3.675+3.916}{3}=3.804
$$

To find out the level of effectiveness of the impact dimension, by entering the average value into the range of the effectiveness rating scale, see the following figure:

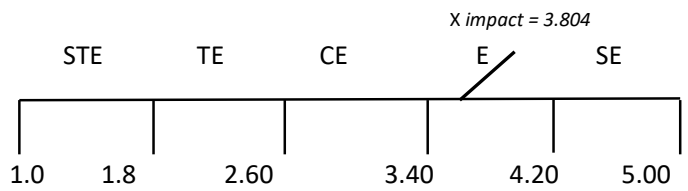

Based on the results of measuring the effectiveness of the Impact dimension, it can conclude that the promotions carried out by FOS Food restaurants are on an effective scale with an average value of 3.804. From the statement indicating that the promotions carried out by FOS Food can involve consumers in the message conveyed and have an impact. FOS Food products stand out from other products in the same category.

\subsubsection{Dimension of Communication}

The calculation of the average score of each item of communication questions is denoted $\mathrm{X}(\mathrm{C} 1)$ to $\mathrm{X}(\mathrm{C} 4)$. The calculation of the score is as follows:

$$
\begin{aligned}
& X(\mathrm{C} 1)=\frac{(1 \times 0)+(2 X 15)+(3 X 32)+(4 \times 47)+(5 \times 14)}{108}=3.555 \\
& X(\mathrm{C} 2)=\frac{(1 \times 0)+(2 X 0)+(3 \times 55)+(4 \times 42)+(5 \times 11)}{108}=3.592 \\
& X(\mathrm{C} 3)=\frac{(1 \times 0)+(2 X 4)+(3 X 9)+(4 \times 59)+(5 \times 36)}{108}=4.175 \\
& X(C 4)=\frac{(1 \times 0)+(2 X 3)+(3 X 48)+(4 \times 48)+(5 \times 9)}{108}=3.583
\end{aligned}
$$

The next step is to determine the average score of the Communication dimension. The calculation of the average score of each item of the Communication dimension question is as follows:

$$
\begin{aligned}
\text { X communication }(C) & =\frac{3.555+3.592+4.175+3.583}{4} \\
= & 3.726
\end{aligned}
$$

To determine the level of effectiveness of the communication dimension by entering the average value into the range of the effectiveness rating scale, see as follows:

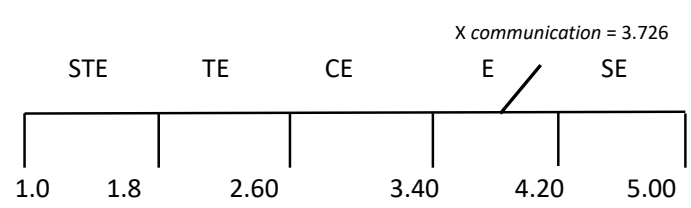

Based on the results of measuring the effectiveness of the Communication dimension, it can conclude that the promotions carried out by FOS Food restaurants are on an effective scale with an average value of 3.726 from the statement indicating that the promotions carried out by FOS Food. Able to provide information to consumers to remember the main message conveyed by consumers' understanding and give the impression left by the message.

\subsubsection{Epic Rate}

After each average score for each dimension of the epic Empathy, Persuasion, Impact, and 
Communication, the results obtain an effective scale range. The next step is to add up all the scores of the four dimensions and divide by the number of dimensions to get the final result of the epic rate, as follows:

$$
\mathrm{X} \text { Epic rate }=\frac{4.121+3.922+3.804+3.726}{4}=3.905
$$

Results based on calculations above the epic rate value obtained is 3.905. This epic rate value is on a scale range of 3.41-4.21, which means that the promotion of the Fos Food Restaurant through Instagram social media is declared effective and the promotion carried out by the Fos Food Restaurant through Instagram social media has quite a positive impact. The last step is to create a chart that aims to see the strengths and weaknesses of each dimension of the epic model in the promotion, as shown in Figure 1. The highest value indicates the strength of a promotion, while the lowest value indicates the weakness of the promotion.

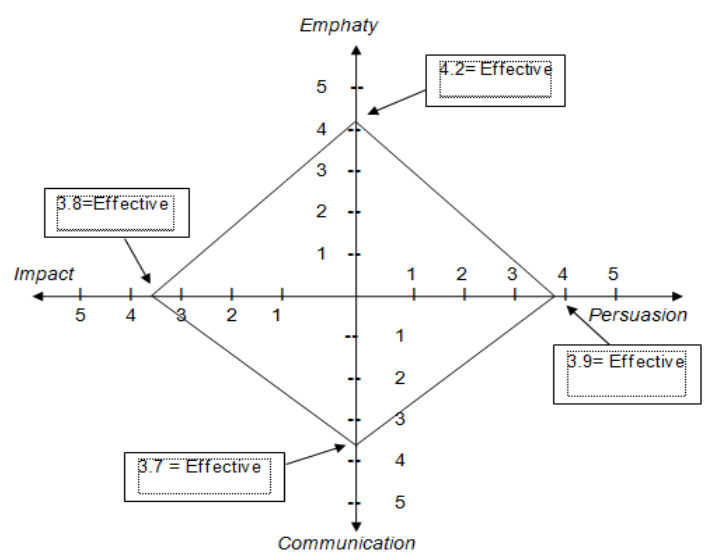

Figure 1 Epic Model

\subsection{Effect of Promotion on Sales Volume}

Table 7 shows the results of the questionnaire on the sales volume. It can explain consumers think that the price of products from FOS Food is less affordable during the Covid 19 pandemics. The respondents' answers support this Disagree with the number of 39 respondents with an average of 2.86 then the results of the questionnaire second question item explain consumers do not often consume FOS Food restaurant products during the Covid 19 pandemics. The respondents' answers support this disagree and quite agree with the number of 33 respondents with an average of 3.13 and the results of the questionnaire third question item that consumers of FOS Food restaurants during the Covid 19 pandemic did not always buy different products. The respondents' answers support this disagree with the number of 52 respondents with an average of 2.81. After each average score for each question is obtained, then add up the scores to see the effectiveness of social media on sales volume, the results obtained are 2.99 and from the results of statements by respondents on the questionnaire, it can be concluded that the sales volume of Fos food restaurants has decreased.

Table 7. Frequency of Respondents to Sales Volume

\begin{tabular}{|c|c|c|c|c|c|c|c|c|c|c|}
\hline \multirow{3}{*}{ Questions } & \multicolumn{10}{|c|}{ Respondent's Answer } \\
\hline & \multicolumn{2}{|c|}{ SD } & \multicolumn{2}{|c|}{ DA } & \multicolumn{2}{|c|}{ QA } & \multicolumn{2}{|c|}{$\overline{\mathbf{A}}$} & \multicolumn{2}{|c|}{ SA } \\
\hline & $\mathbf{F}$ & $\%$ & $\mathbf{F}$ & $\%$ & $\mathbf{F}$ & $\%$ & $\mathbf{F}$ & $\%$ & $\mathbf{F}$ & $\%$ \\
\hline $\begin{array}{l}\text { Affordabl } \\
\text { e product } \\
\text { prices }\end{array}$ & 6 & $\begin{array}{l}5 . \\
6\end{array}$ & $\begin{array}{l}3 \\
9\end{array}$ & $\begin{array}{c}36 . \\
1\end{array}$ & $\begin{array}{l}3 \\
7\end{array}$ & $\begin{array}{r}34 . \\
3\end{array}$ & $\begin{array}{l}1 \\
6\end{array}$ & $\begin{array}{c}14 . \\
8\end{array}$ & 1 & 9.3 \\
\hline $\begin{array}{l}\text { Consumin } \\
\mathrm{g} \text { often } \\
\text { (buying } \\
\text { intensity) }\end{array}$ & 6 & $\begin{array}{l}5 . \\
6\end{array}$ & $\begin{array}{l}3 \\
3\end{array}$ & $\begin{array}{c}30 . \\
6\end{array}$ & $\begin{array}{l}3 \\
3\end{array}$ & $\begin{array}{r}30 . \\
6\end{array}$ & $\begin{array}{l}1 \\
2\end{array}$ & $\begin{array}{c}11 . \\
1\end{array}$ & $\begin{array}{l}2 \\
4\end{array}$ & $\begin{array}{c}22 . \\
2\end{array}$ \\
\hline $\begin{array}{l}\text { Buy } \\
\text { different } \\
\text { products }\end{array}$ & 2 & $\begin{array}{l}. \\
9\end{array}$ & $\begin{array}{l}5 \\
2\end{array}$ & $\begin{array}{c}48 . \\
1\end{array}$ & $\begin{array}{l}2 \\
4\end{array}$ & $\begin{array}{r}22 . \\
2\end{array}$ & $\begin{array}{l}2 \\
4\end{array}$ & $\begin{array}{c}22 . \\
2\end{array}$ & 6 & 5.6 \\
\hline
\end{tabular}

Source: Primary Data, 2021

This is also supported by the volume of visits to FOS food restaurants in 1 month during the covid 19 pandemic, as shown in Table 8. 
Table 8. Respondents Frequency of Visiting Volume

\begin{tabular}{|c|c|c|c|}
\hline No & Visits (times) & Total visits (people) & Percentage (\%) \\
\hline 1 & $2-3$ & 80 & 74.1 \\
\hline 2 & $4-5$ & 26 & 24.1 \\
\hline 3 & $>5$ & 2 & 1.9 \\
\hline \multicolumn{2}{|c|}{ Total } & $\mathbf{1 0 8}$ & $\mathbf{1 0 0}$ \\
\hline
\end{tabular}

Source: Primary Data, 2021

Based on the data on the volume of visits in the table above, it can see that the respondents who visited the FOS Food restaurant for one month during the COVID-19 pandemic were 2 to 3 times totaling 80 people with a percentage of $74.1 \%$, and respondents who visited the FOS Food restaurant during the pandemic. Covid 194 to 5 times totaling 26 people with a percentage of $24.1 \%$ while respondents who visited the FOS food restaurant during the covid 19 pandemic more than five times amounted to 2 people with a percentage of $1.9 \%$. It can conclude that consumers who visited FOS Food's restaurant in 1 month during the covid 19 pandemics were 2 to 3 times totaling 80 people with a percentage of 74 .

\section{CONCLUSION}

The effectiveness of FOS Food Restaurant promotion through Instagram social media was studied using the Epic model. The obtained Epic rate was 3.905. Thus, it can conclude that included the promotions carried out by the FOS Food Mojokerto restaurant in the era of the Covid 19 pandemic was in the effective scale range. Meanwhile, the effect of restaurant promotions on sales volume during the Covid 19 pandemic, based on the results of the questionnaire distribution, that consumers think that the price of products from FOS Food is less affordable during the Covid 19 pandemic. It was based on respondents who disagree with 39 respondents with an average of 2.86, while consumer answers assume that they do not often consume FOS Food restaurant products during the covid 19 pandemic. Respondents' answers support this disagree and quite agree with the number of 33 respondents with an average of 3.13 , and consumer answers think that you do not always buy a different product. The respondents' answers support this disagree with the number of 52 respondents with an average of 2.81. Consumers who visited FOS Food restaurant for 2 to 3 times in one month during the Covid 19 pandemic amounted to 80 people with a percentage of $74.1 \%$.

Based on these conclusions, the following suggestions can give by researchers, include:

1. For promotion through social media Instagram, the product of the FOS Food Mojokerto restaurant, which has a smaller score, is the Impact dimension. This result shows that the respondents have not fully received a meaningful impact in the promotion; therefore, the promotion of the FOS Food restaurant must be more creative in conveying the promotion so that consumers get a significant impact in the promotion. Thus, the sales volume at FOS Food restaurants can continue to increase.

2. It is necessary to research further the analysis of promotional activities using different analytical tools, for example, by using multiple linear regression analysis and structural equation models to determine the wider impact of the promotion. In addition, the obstacle in this study is the difficulty of finding respondents who visit or buyers at FOS Food restaurants, the lack of consumer purchasing power causes this due to social distance due to the spread of covid 19 to advice to work from home and close all public service sectors. Meanwhile, finding respondents who visit and buy at restaurants is very important because it may make it easier for respondents to fill out questionnaires so that the 
results are valid. Thus, it is recommended for parties who want to do similar research to look for respondents with online questionnaires and have seen the promotion was studying so that the research results will be more valid.

\section{REFERENCES}

[1] Wati et al., "Effectiveness Analysis of Marketing System Anugerah Mina Lestari SME Using Facebook Social Media, JAFH Journal, vol. 9, No. 1, 2020.

[2] C. A. Elena, "Social Media-A strategy in developing customer relationship management," Procedia Econ. Financ., vol. 39, pp. 785-790, 2016.

[3] Hariyanti, N. T., and Wirapraja, A, "the influence of influencer marketing as a digital marketing strategy for the modern era,", Journal Eksekutif, vol. 15, No. 1, pp. 133-146, 2018.

[4] Personal, 16 Effective Ways to Bring Customers Through the Internet. 2010.

[5] P. Charoensukmongkol and P. Sasatanun, "Asia Pacific Management Review Social media use for CRM and business performance satisfaction: The moderating roles of social skills and social media sales intensity," Asia Pacific Manag. Rev., vol. 22, no. 1, pp. 25-34, 2017.

[6] Ibrahim A et al. "The Effectiveness of Instagram Features as a Sales Promotion Media Using Discrepancy Evaluation Model Method in Increasing Customer Loyalty," Advances in Intelligent Systems Research, vol. 172, pp. 665-673, 2020.

[7] A. Rukajat, Quantitative Research Approach: Quantitative Research Approach, CV BUDIMAN. Yogyakarta, 2012.

[8] P. Pad, D. A. N. D. B. H. Against, P. B. Modal, D. A. General, and D. B. Results, "Effect of Pad, Dau, Dak, and Dbh on Capital
Expenditure Allocation," Account. anal. J., vol. 2, no. 1, 2013.

[9] E. P. Widoyoko, "Optimizing the Role of Teachers in Evaluation," J. . Educator, vol. 22, no. 2, pp. 177-186, 2013.

[10] A. Dinda, D. Rara, and Irwansyah, "Effectiveness of traveloka youtube ads on purchasing decisions," Demandia, vol. 3, pp. 77-96, 2018, [Online]. Available: https://journals.telkomuniversity.ac.id/demandi a/article/view/1212.

[11] Sugiyono, Quantitative, Qualitative, and R\&D Research Methods. 1st ed. Bandung: Alphabeta, 2019..

[12] G. Imam., Application of Multivariate Analysis with SPSS Program. Semarang: Diponegoro University, 2009. 